Journal of Finance and Banking Review

Journal homepage: www. gatrenterprise. com/GATRJournals/index. htm

J. Fin. Bank. Review 4 (2) 58-63 (2019)

\title{
How Impactful is Telecom Efficiency to Company Stock Value?
}

\author{
Riko Hendrawan, ${ }^{*}$ Kristian WA Nugroho, $^{2}$ Gayuh T Permana ${ }^{3}$ \\ 1,2,3 Telkom University, J1. Gegerkalong Hilir No. 47, 40251, Bandung, Indonesia
}

\begin{abstract}
Objective - The telecom industry is one of the optimistic industries that is still growing. In South East Asia, between 2008-2017, the number of subscribers increased 10.07\% annually, and revenue for the industry grew $6.08 \%$ annually. However, Net Profit Margin, EBITDA, and EBIT value during the same period declined at the time revenue amount was increasing. One of the visible health factors and part of the valuation factor is stock value. Hence the research question of this study is: What is the impact and significance of telecom operators' efficiency to stock value?

Methodology/Technique - In this study, efficiency will be measured and analyzed using Stochastic Frontier Approach (SFA) method. By using same method, the impact of efficiency to stock value will be measured, as well as the significance level.

Findings - The results of this research show that from 14 telecom operators observed, TLKM (Indonesia) obtained the highest efficiency score (0.984) whereas StarHub (Malaysia) had the lowest efficiency score (0.405). TLKM (Indonesia) and AIS (Thailand) had a similar efficiency score given the fact that the behaviour of the subscribers is similar and they have the same country characteristic.

Novelty - All of the input and output variables have a positive impact on the efficiency parameter except Total Asset which has negative impact on the efficiency score. By using further analysis of the t-Ratio between the variables and efficiency, it can be seen that stock value is impacted by the efficiency parameters but this impact is not significant ( $t$ Ratio 1.35).

Type of Paper: Empirical.
\end{abstract}

Keywords: Efficiency; Telecom Operators; Stock Value, Indonesia.

Reference to this paper should be made as follows: Hendrawan, R.; Nugroho, K. WA. Permana, G. T. (2019). How Impactful is Telecom Efficiency to Company Stock Value?, J. Fin. Bank. Review, 4 (2): 58 - 63 https://doi.org/10.35609/jfbr.2019.4.2(2)

JEL Classification: G14, G32, G39.

\section{Introduction}

The telecom industry has a very large contribution in providing connectivity services to customers in the digital era.

\footnotetext{
* Paper Info: Received: March 11, 2019

Accepted: July 11, 2019

* Corresponding author: Riko Hendrawan

E-mail: riko_hendrawan@yahoo.com

Affiliation: Faculty Economic and Business, Telkom University, Indonesia
} 
This opportunity creates huge digital prospects, particularly for emerging market economies in ASEAN \& ASEAN-Indochina (Ure, 2008). Data from telecom operators in South East Asia shows that during last 10 years, the number of subscribers has increased almost $10.07 \%$ annually, from 177 million to 463 million subscribers. A similar trend can be seen in revenue which has steadily grown $6.08 \%$ annually. On the other hand, some financial parameters such as Net Profit Margin (NPM), EBITDA and EBIT value during the same period experienced a decline. This phenomenon has driven further research on efficiency factors of telecom operators.

Evaluating company performance can be conducted in many ways, such as measuring the efficiency as well as calculating corporate valuation. Measuring performance itself will use various methods based on unit cost, profit per unit, and so forth. The ratio of output and input in a production flow is commonly used in efficiency evaluation (Cooper, 2007). Previous studies, such as those by Baysal, Altun and Toklu (2007), Jin, D. Y. (2006), Torres and Bachiller (2011), Masson, Jain, Ganesh and George (2016), Hendrawan and Nugroho (2018) measured telecom companies' efficiency in Turkey, Taiwan, Asia-Pacific, Europe, India, and Indonesia. Al-Farisi and Hendrawan $(2010,2011)$ used the DFA approach to measure the efficiency of the banking industry in Indonesia. Gaster and Hundekar (2017) on the other hand studied financial performance of telecom operators in India.

One of the visible health factors and subject of corporate valuation is stock value. Hence, the research question of this study is: What is the impact and significance of telecom operators' efficiency on stock value?

Telecom operator organizations, also known as mobile network operators, cellular companies, wireless carriers, or wireless service providers, are organizations that provide wireless communication services to its customers. In the current digital era, the services offered by telecom companies will be more diverse and suited to their customer's needs, such as the digital wallet, content subscription, handset bundling services and so on.

\section{Literature Review}

Measuring the efficiency of a company can be achieved using several approaches. Saxena, Thakur, and Singh (2009) have categorized the measurement methods into the average method and the frontier method. The average method is performed by comparing target variables with the average performance indicator, whilst the frontier method uses a comparison of variables by taking the best value of compared ones. Berger (1997) states that Stochastic Frontier Analysis (SFA) is one of the parametric approaches of the frontier method that is used for measuring cost, profit, or production relationships between the input and output variables. The advantage of the SFA approach compared to other parametric methods is that it includes error calculations, namely random error (assumed following symmetrical standard distribution) and cost inefficiency (assumed following asymmetrical standard distribution).

Damodaran (2006) states that the prerequisite to correct decision making in portfolio investment is knowing the value of an asset as an investment object and to understand what provides value to those assets. To acquire a benefit, the investors will invest whenever the price is under the fair value. The price of an investment in an organization is determined by the stock value. The value of a company is impacted by the business condition of the organization, as well as external and internal factors.

Karlsson, Back, Vanharanta and Visa (2001) conducted a study on the performance of 88 companies in various countries between 1995 and 1999. The results show that six classification groups of telecom companies are based on financial ratio efficiency. The best class of classification which had very good efficiency profit also had a very high financial ratio on Operating Margin, ROA, and ROE.

Another study concerning an efficiency comparison was performed by Jin, D. Y. (2006) on telecom companies in the Asia-Pacific region using data from between 1993 to 2004 with a Stochastic Frontier (SF) method to calculate the Technical Efficiency based on input variables: capital amount calculated from telecom investment, number of employees, number of subscribers, and aggregate revenue as output variables. 
The conclusion of that research was that the efficiency value of telecom operators in the United States was much higher than in developing countries in the Asia-Pacific, and privatization was contributing to technical efficiency scores.

Al-Farisi and Hendrawan (2011) examined the banking industry in Indonesia between 2002 and 2008 using a Distribution Free Approach (DFA) to measure the profit efficiency value of each company and analyze the impact of capital ratio on banking performance. The research results show that the average Indonesian banking industry efficiency score was 0.6 which indicates that Sharia banks placed among the top $20 \%$ of highest profit efficiency scores. A recent study of telecom industry efficiency was also conducted by Nigam, V., Thakur, T., Sethi, V. K., \& Singh, R. P. (2012). on Bharti Airtel by analyzing short-term and long-term financial positions to determine a company's profit level. In that study, it was concluded that Bharti Airtel was in a good condition in terms of company performance and could be further improved by focusing on its operations, administration and reducing expenditure.

\section{Research Methodology}

This study uses data from the financial statements of telecom operators in South East Asia between 2008 and 2017. The input variables used are capital expenditure, operating expense, personnel expense, and total asset. The output variables include revenue amount, number of subscribers, ARPU, and stock value. Of 53 active telecom operators registered in the GSM Association in 11 countries, 14 companies are selected using a purposive sampling method with the following criteria: (1) had positive growth of stock value in 20082017, (2) minimum number of customers is 1 million, (3) have published financial reports in 2008-2017. The telecom operators selected are: StarHub, Singtel, and M1 from Singapore; Globe Telecom and Smart PLDT from Philippines; Telkomsel, Indosat, and XL Axiata from Indonesia; Celcom, DiGi, and Maxis from Malaysia; as well as AIS, DTAC Telenor, and TrueMove from Thailand.

The output parameters that represent the profit function in this study was developed by Berger and Di Patti (2006) and Berger and Mester (1997), which are used to evaluate how close a company obtains profit as achieved by the best company within same exigent condition. The profit is representing a function of input, output, and environment variables as follows:

$$
\ln (\pi)=f_{\pi}(y, w, v)+\ln u_{\pi}+\ln \varepsilon_{\pi}
$$

Where $\pi$ represents the profit variable, y represents the output variables, $w$ represents the input variables, and $\mathrm{v}$ represents the environmental variables that might influence corporate performance. In addition, $\mathrm{u}$ represents the controllable factors that might influence efficiency, while $\epsilon$ represents the uncontrollable factors or random errors. Efficiency scores will be measured and compared following the SFA approach, and then a regression will be performed to identify the significance level of each variables and their impact on efficiency. 


\section{Results}

Table 1. Efficiency Score Results of Telecom Operators

\begin{tabular}{|c|l|c|}
\hline \#Rank & Operator & Efficiency Score \\
\hline 1 & TLKM & 0.984 \\
\hline 2 & AIS & 0.978 \\
\hline 3 & Maxis & 0.866 \\
\hline 4 & Celcom (Axiata) & 0.784 \\
\hline 5 & Smart (PLDT) & 0.748 \\
\hline 6 & DiGi & 0.732 \\
\hline 7 & dtac (Telenor) & 0.712 \\
\hline 8 & XL & 0.651 \\
\hline 9 & Globe Telecom & 0.638 \\
\hline 10 & ISAT & 0.603 \\
\hline 11 & TrueMove H & 0.555 \\
\hline 12 & Singtel & 0.508 \\
\hline 13 & M1 & 0.455 \\
\hline 14 & StarHub & 0.405 \\
\hline & Average & 0.687 \\
\hline
\end{tabular}

The results of this research show that of the 14 telecom operators observed, TLKM (Indonesia) obtained the highest efficiency score (0.984) whereas StarHub (Malaysia) had the lowest efficiency score (0.405). TLKM (Indonesia) and AIS (Thailand) had almost similar efficiency scores given that the behavior of their subscribers are similar and they have the same country characteristic. The average efficiency score of the telecom companies in this study is 0.687 .

Table 2. Factors Influencing Efficiency Score

\begin{tabular}{lccclc}
\hline Variable & Coefficient & Std-Error & t-Ratio & Significance & Impact \\
\hline Revenue & 6.38 & 0.36 & 17.65 & Significant * & Positive \\
\hline Capex & 0.01 & 0.00 & 2.47 & Significant ** & Positive \\
\hline Opex & 0.51 & 0.02 & 27.87 & Significant * & Positive \\
\hline Total Asset & -0.08 & 0.02 & -4.37 & Significant * & Negative \\
\hline Personal Expenses & 0.10 & 0.01 & 7.79 & Significant * & Positive \\
\hline Subs & 0.22 & 0.02 & 11.00 & Significant * & Positive \\
\hline ARPU & 0.02 & 0.00 & 6.38 & Significant * & Positive \\
\hline Stock Value & 0.00 & 0.00 & 1.35 & Not Significant & Positive \\
\hline $\begin{array}{l}\text { Remarks: } \\
* \text { Significant } \alpha=1 \%\end{array}$ & & & & & \\
$* *$ Significant $\alpha=5 \%$ & & & & & \\
$* *$ Significant $\alpha=10 \%$ & & & & &
\end{tabular}

All of the input and output variables have a positive impact on efficiency except Total Asset, which has a negative impact on efficiency. Further analysis of the t-Ratio between the variables and efficiency shows that stock value is impacted by efficiency but this impact is not significant (t-Ratio 1.35).

\section{Discussion}

TLKM (Indonesia) has the highest efficiency score of 0.984 compared to other telecom operators in South-East Asia. Some variables value owned by TLKM were far more superior than others; such as $121 \%$ 
higher capital expenditure, $124 \%$ revenue, and $288 \%$ number of subscribers. The ARPU value of TLKM has a fairly small coefficient and below average value compared with other telecom companies.

AIS (Thailand) occupied 2nd position with an efficiency score of 0.978 which was $42 \%$ higher than the average. It was reported that AIS had an $80 \%$ advantage in capital expenditure and $103 \%$ in operating expenses variable, meanwhile its total asset and personal expenses were lower than average, $-39 \%$ and $-34 \%$ respectively. In addition, AIS' number of subscribers is $14 \%$ higher than the average number of subscribers of the other telecom operators. This profile is quite similar to that of TLKM (Indonesia).

The lowest efficiency score among the 14 telecom operators was obtained by StarHub (Singapore) with a value of 0.405 . This result was caused by the very low value of variables that contributed positively to the efficiency value, such as very low amount of revenue and number of subscribers, as well as a high number of total asset variables that contributed negatively to the efficiency value.

Table 2 shows that capital expenditure, operating expenses, total assets and personal expenses have a significant impact on efficiency among telecom operators to varying degrees of $\alpha$. Capex, Opex, and personal expenses have a positive impact on efficiency, as evidenced by the coefficient value, meaning that an increase in these variables will cause an increase in efficiency. In contrast, total assets has a negative impact on efficiency. All other output variables also had a significant and positive impact on efficiency, except stock value which does not have a significant impact.

The positive value of the coefficient parameter indicates a positive relationship in which an increase in value of the variable will cause an increase in efficiency. As shown in Table 2, the variables that have a positive coefficient parameter include: revenue amount (6.38), capital expenditure (0.01), operating expense (0.51), personal expense (0.1), number of subscribers (0.22), and average revenue per user (0.02). On the other hand, the variables with a negative value of coefficient shows negative relationship whereby an increase in the value of the variable will cause a decrease in efficiency. In this case, the variable with a negative coefficient is total asset (-0.08).

All variables have a significant impact on efficiency either positively or negatively, with the exception of stock value. The T-Ratio of each variable can be described as follows: revenue amount (17.65), capital expenditure (2.47), operating expenses (27.87), total asset (-4.37), personal expenses (7.79), number of subscribers (11.00), average revenue per user (1.35). Those variables are categorized as variables that have a significant impact on efficiency by assuming $\alpha$ more than $1 \%$. On the other hand, stock value has a t-ratio of 1.35 which is categorized as non-significant.

\section{Conclusion}

TLKM (Indonesia) is the most efficient telecom operator in South East Asia based on its financial statement between 2008-2017. Seven telecom operators achieved an efficiency score above the average value (0.687). These include: TLKM, AIS, Maxis, Celcom, Smart (PLDT), DiGi, and dtac (Telenor. All other operators achieved below average efficiency scores.

Telecom operators can increase their efficiency by increasing their input parameters such as capital expenditure, operational expenses and personal expenses. An increase in Total Assets should be maintained to achieve maximum efficiency. Since efficiency has an impact but is not-significant on stock value, management should differentiate the focus of their financial strategies upon the two parameters, achieving a healthy financial structure with efficiency parameters and having a good valuation with sufficient stock value.

Those conclusions are applicable for the object on this research, which consists of 14 telecom operators in South East Asia based on 10 years of financial data. 


\section{References}

Al-Farisi, A. S., \& Hendrawan, R. (2010). Measuring Efficiency as Intermediation Approach Between Conventional and Sharia Banks in Indonesia. Journal of Finance and Banking, 14 (3), http://jurnal.unmer.ac.id/index.php/jkdp/article/view/991

Al-Farisi, A.S and Hendrawan, R, (2011). "Effect of Capital Structure on Bank Performance: Profit Efficiency Approach Islamic and Conventional Banks Case in Indonesia". International Research Journal of Finance and Economics, http://dx.doi.org/10.2139/ssrn.1895211

Baysal, M. E., Altun, D., and Toklu, B. (2007). “An Efficiency Study in Turkish Telecommunication Company Using Data Envelopment Analysis". Beykent University Journal of Science and Technology. 1(1). 58-71, http://hdl.handle.net/123456789/493

Berger, A. N., \& Humphrey, D. B. (1997). Efficiency of financial institutions: International survey and directions for future research. European journal of operational research, 98(2), 175-212, https://doi.org/10.1016/S03772217(96)00342-6

Berger, A. N., \& Di Patti, E. B. (2006). Capital structure and firm performance: A new approach to testing agency theory and an application to the banking industry. Journal of Banking \& Finance, 30(4), 1065-1102, https://doi.org/10.1016/j.jbankfin.2005.05.015

Cooper, W.W., Seiford, L.M., and Tone, K., (2007). Data Envelopment Analysis: A Comprehensive Text with Models, Application, References and DEA-Solver Software. New York. Springer. 10.1007/978-0-387-45283-8

Damodaran, A. (2016). Damodaran on valuation: security analysis for investment and corporate finance (Vol. 324). John Wiley \& Sons.

Gaste, M., Hundekar, R. Vanishri., (2017). "Financial Performance of Telecommunications Companies". International Research Journal of Engineering and Technology, 4(11), 1388-1390 https://www.irjet.net/archives/V4/i11/IRJETV4I11253.pdf

Hendrawan, R, and Nugroho, K.W.A, (2018). "Telecommunication Sector Reform in Southeast Asia: A New Rationality". Global Journal of Business and Social Science Review, 6(4), 147-154, https://papers.ssrn.com/sol3/papers.cfm?abstract_id=3307325

Jin, D. Y. (2006). Political and economic processes in the privatization of the Korea telecommunications industry: A case study of Korea Telecom, 1987-2003. Telecommunications Policy, 30(1), 3-13, https://doi.org/10.1016/j.telpol.2005.08.002

Karlsson, J., Back, B., Vanharanta, H., \& Visa, A. (2001). Financial benchmarking of telecommunications companies. Turku: Turku Centre for Computer Science, https://pdfs.semanticscholar.org/6ed8/1e07f838e79111ef03df897f3d13c59c2c42.pdf

Masson, S., Jain, R., Ganesh, N.M., and George, S.A. (2016). Operational Efficiency and Service Delivery Performance: A Comparative Analysis of Indian Telecom Service Providers. Benchmarking: An International Journal. 23 (4). 893-915. https://doi.org/10.1108/14635770810903169

Nigam, V., Thakur, T., Sethi, V. K., \& Singh, R. P. (2012). Benchmarking of Indian mobile telecom operators using DEA with sensitivity analysis. Benchmarking: An International Journal, 19(2), 219-238, https://doi.org/10.1108/14635771211224545

Saxena, V., Thakur, T., and Singh, R.P., (2009). Evaluating the Performance of Mobile Telecom Operators in India. International Journal of Simulation System, Science, \& Technology IJSSST, Vol 10, No, 4 https://doi.org/10.1108/14635771211224545

Torres, L., \& Bachiller, P. (2013). Efficiency of telecommunications companies in European countries. Journal of Management \& Governance, 17(4), 863-886, https://link.springer.com/article/10.1007/s10997-011-9203-4

Ure, J. (Ed.). (2008). Telecommunications Development in Asia. Hong Kong University Press 